\title{
Functioning of Fama-French Three-Factor Model in Emerging Stock Markets: An Empirical Study on Chittagong Stock Exchange, Bangladesh
}

\author{
Emon Kalyan Chowdhury \\ School of Business, Chittagong Independent University, Chittagong, Bangladesh \\ Email: emonkalyanchy@gmail.com
}

How to cite this paper: Chowdhury, E. K. (2017). Functioning of Fama-French ThreeFactor Model in Emerging Stock Markets: An Empirical Study on Chittagong Stock Exchange, Bangladesh. Journal of Financial Risk Management, 6, 352-363. https://doi.org/10.4236/jfrm.2017.64025

Received: October 7, 2017

Accepted: November 25, 2017

Published: November 28, 2017

Copyright $\odot 2017$ by author and Scientific Research Publishing Inc. This work is licensed under the Creative Commons Attribution International License (CC BY 4.0).

http://creativecommons.org/licenses/by/4.0/

(c) (i) Open Access

\begin{abstract}
This paper attempts to test the functioning of Fama-French (FF) three-factor model at Chittagong Stock Exchange (CSE). The three factors include market risk premium, size risk and book to market risk. Nine portfolios are constructed by taking daily closing prices of thirty selective stocks of CSE from January 2010 to December 2014. Treasury bill rates of Bangladesh are used as a proxy for the risk-free rate. This study finds, stocks with small market capital outperform that of large market capital. It also observes that higher book to market ratio yields poor earnings. Although return at CSE is significantly influenced by rational size, it is weakly affected by value. Being a rumor driven and inefficient market, the FF model has positive but weaker explanatory capacity on stock returns at CSE.
\end{abstract}

\section{Keywords}

Fama-French, Asset Pricing, CSE, Risk, Returns

\section{Introduction}

Capital Asset Pricing Model (CAPM) advocates that market beta determines the variation in stock returns (Breeden, 1979). Fama and French (2004) observed very little relation between market beta and stock return whereas other studies found relationships between returns and variables such as "size", "book to market ratio", and "past returns" popularly known as market capitalization, BM and risk premium respectively. It is evident that the relationship between risk and return cannot be explained by a single-factor CAPM appropriately. In fact, no 
model so far developed can accurately explain the relation. The most universal and acceptable model in the current finance arena is the three-factor model instrumented by Fama and French. This model assumes that the cross-section of average returns can be explained by three factors like the excess market return, size factor and book-to-market (B/M) equity factor. Fama and French in 1992 extended the original CAPM by introducing two additional factors viz., size and book to market which can explain the cross-section of stock returns. SMB, which stands for Small Minus Big, measures the additional returns which have historically been received from investment in stocks of companies with comparatively small market capitalization. This additional return is known as the "size premium". HML, which stands for High Minus Low, measures the "value premium" given to investors for investing in companies having high book-to-market values. SMB which measures "size risk" reflects the view that small companies supposed to be more sensitive to many risk factors as they are comparatively undiversified in nature and have little ability to undertake adverse financial situations. HML factor advocates higher risk exposure for typical "value" stocks with high $\mathrm{B} / \mathrm{M}$ and "growth" stocks with low $\mathrm{B} / \mathrm{M}$. This is quite rational because companies need to arrive at a minimum size in order to execute an Initial Public Offering. Companies with high $\mathrm{B} / \mathrm{M}$ indicate that their public market value has dropped because of hard times or uncertainty regarding future earnings. For any given asset, particularly at the time of giving dividends, the objective of the company is to characterize the "reasonable" price or the set of "reasonable" prices. Reasonable price is characterized by quality and quantity of products or services, terms of payment, favorable delivery and availability at the right time. It is also known as an equilibrium price. An equilibrium price is found in two situations, first, when supply is equal to demand for any asset, i.e. markets clear, and the second situation is when an investor is satisfied with his present position and the asset prices.

\section{Literature Review}

Over the last forty years, substantial research has been done to test the applicability of the Capital Asset Pricing Model (CAPM) of Sharpe (1964), Lintner (1965), and Black (1972). Many researchers found the validity of the model (e.g., Lintner, 1965; Black et al., 1972; Fama \& MacBeth, 1973). According to the CAPM, capital market is supposed to be efficient and equilibrium, there should have positive and linear relationship between expected return on a risky asset and its systematic risk (or market beta). However, in finance literature, apart from market beta there are several firm-specific factors which effect the explanatory power of market returns, for example, firm size (e.g., Herrera \& Lockwood, 1994; Reinganum, 1981, 1982; Banz, 1981), book-to-market equity ratio (B/M) (e.g., Chan et al., 1991; Rosenberg et al., 1985; and earnings-to-price ratio (E/P) (e.g., Jaffe et al., 1989; Basu, 1977, 1983). The increasing empirical evidence on these "anomalous" variables inspired Fama and French (1992) to examine the 
joint roles of market beta and few firm-specific variables in the cross-section of average returns on the US stocks. They find $\mathrm{B} / \mathrm{M}$ and size play significant roles to describe average returns. In an extension of their results, Fama and French (1993) (henceforth FF), based on the traditional CAPM, advocate a three-factor asset pricing model to include two firm-specific characteristics. The three-factor model of FF includes a market factor (excess market return), a size factor (SMB), and a $\mathrm{B} / \mathrm{M}$ factor (HML). SMB (Small Minus Big) is the return on a portfolio of small stocks minus the return on a portfolio of big stocks and HML (High Minus Low) is the return on a portfolio of value stocks minus the return on a portfolio of growth stocks in terms of $\mathrm{B} / \mathrm{M}$. FF observe that at the initial stage their three-factor model fails to explain return variation. Fama and French (1996) again observe that the three-factor model successfully capture almost all known anomalies, with one exception and that is the short-term momentum strategy of Jegadeesh and Titman (1993). The other anomalies (cash flow yield, E/P, sales growth, long-term past return) disappear in the three-factor model. In today's world one of the most hotly debated anomalies is the momentum effect which indicates past winners (losers) perform well (poorly). Momentum strategy is about buying stocks with high returns and selling stocks with low returns. This policy generates significant profits, Jegadeesh and Titman's (1993). Carhart (1997) comes out with a risk factor related to momentum effect (WML), and recommends a four-factor model by adding this risk factor with the existing FF three-factor model. WML (winners minus losers) implies the return on a portfolio of winner-stocks minus the return on a portfolio of loser-stocks. He finds that, his four-factor model remarkably reduces the average pricing errors of portfolios compared to the FF three-factor model sorted by 1-year lagged returns. It is clearly evidenced in Daniel et al. (1997) and Wermers (1997) that the Carhart's (1997) fourth factor does well in examining the strategies that ensures consistency in mutual fund performance. Brav et al. (2000) find that the four factors can explain the under-performance in returns from both initial public offering (IPO) and seasoned equity offering (SEO) firms. Kim and Kim (2003) find that the four-factor model can explain the abnormal nature of the postearning announced returns, which are arranged by standardized unexpected earnings. Liew and Vassalou (2000) examine the excess returns from the SMB, HML, and WML factors by taking data from ten developed markets. They find high premiums for the three factors in four, nine, and eight markets, respectively. L'Her et al. (2004) find applicability of a four-factor pricing model in the Canadian stock market where it proves that the average annual premiums obtained for the market, size, $\mathrm{B} / \mathrm{M}$ and momentum risk factors. In the Asian markets, Wong and Lye (1990) and Lau et al. (2002) observe significant size effect in the Singaporean stock market. Mukherji et al. (1997) notice that annual returns on the Korean stocks are highly related to size and B/M. Ho et al. (2000) and Lam (2002) find significant size and B/M effects in Hong Kong stock market. In another comprehensive study, Chui and Wei (1998) find that B/M can elucidate the cross-sectional variation of expected returns in Malaysia, Hong Kong, and 
Korea whereas the size effect is found significant in all the markets except Taiwan. It should be mentioned that all the above studies do not use the specific FF three-factor model in their analysis therefore no zero-investment portfolios are formed on the basis of size and B/M factors. Whereas, they use firm size and $\mathrm{B} / \mathrm{M}$ ratio as descriptive variables directly in their regression models. There are very few studies to check the robustness of the FF three-factor model in the Asian markets. Drew and Veeraraghavan (2003) examine the explanatory power of the FF three-factor model for Hong Kong, Korea, Malaysia, and Philippines. They find both size and $\mathrm{B} / \mathrm{M}$ effects in all the markets and propose that the three-factor model suggests a narrow description of the average returns for these Asian markets over the 1990s. Shum and Tang (2005) inspect the application of the FF three-factor model in the Hong Kong, Singaporean, and Taiwanese markets and observe similar results to Drew and Veeraraghavan's (2003). There is very limited research regarding the role of momentum strategies in the Asia context. These studies (e.g., Chan et al., 2000; Chui et al., 2000; Grundy \& Martin, 2001; Fong et al., 2005) find the evidence of the profitability of the momentum strategies in some Asian markets. The three factor Fama-French model has been applied in most of the large and highly regulated exchanges all over the world. Since the factors also characterize the small, independent and relatively less regulated exchanges, this study attempts to observe the functioning capacity of Fama-French model at Chittagong Stock Exchange in Bangladesh.

\section{Data and Methodology}

The main objective of this study is to test the functionality of the Fama and French three-factor model in the Chittagong Stock Exchange (CSE). Formal trading started at CSE on October 10 1995. At that time, the trading system was manual (cry-out). From June 2 1998, the trading system was converted to automation. Being a demutualized exchange, CSE is also proud partner of United Nation's sustainable stock exchange initiative. This exchange is the highly influential stock market in Bangladesh with a total capitalization of over 30 billion US dollars (http://www.cse.com.bd). At present, there are 295 stocks trading on CSE spreading over twenty different sectors. This research applies the same methodology instrumented by Fama and French in 1996. The current study has a daily-based test period from January 2010 to December 2014. This study includes only those companies which have data more than five years. This time restriction contributes to the reliability of the data. Gaunt (2004) used a similar strategy (18-month restriction) in his study. Out of 295 stocks, only best performing 30 stocks have been chosen for this study. The best performing companies of CSE belong to CSE-30 index. The major criteria for a company to fall under CSE-30 index are;

- Basic Criteria

a) Regularly holds Annual General Meeting and minimum market capital is Bangladesh Taka 200 million, which is at least two times of paid up capital.

b) Having positive revenues or retained earnings. 
c) Should be traded minimum 50\% trading days of the six monthly review period.

d) Pay dividend at least once in last two years.

e) Should not have negative Earnings Per Share (EPS) for the last two consecutive years.

f) Financial institutions should not fall under the problem list of Bangladesh Bank (central bank of Bangladesh) etc.

- Selection Criteria

a) Higher Earning Per Share, Dividend Per Share, Net Assets Value, rate of floating equity, liquidity,

b) Larger number of shareholders

c) Lower Price-Earning (P/E) Ratio etc.

The Fama and French three-factor model regression equation is stated as;

$$
R_{i j}-R_{f t}=a_{i t}+b_{i t}\left(R_{M t}-R_{f t}\right)+S_{i t}(S M B)+h_{i t}(H M L)+e_{i t}
$$

In this equation:

$R_{i t}$ Return on security or portfolio $i$ for period $t$,

$R F_{i}$ Risk-free return,

$R M_{i}$ Return on the value-weight (VW) market portfolio,

$S M B_{\mathrm{t}}$ : Return on a diversified portfolio of small stocks minus the return on a diversified portfolio of big stocks,

$H M L$ t: Difference between the returns on diversified portfolios of high and low $B / M$ stocks,

$e_{i i}$ : Zero-mean residual.

The return of selected stocks is used as a proxy for the market portfolio. Daily returns of three or six-month Treasury bill rates are used as a proxy for the riskfree rate. The second risk factor, calculated as small minus big (SMB), is the difference in returns on a portfolio of small stocks and on a portfolio of big stocks. Here, small and big refers to size of the market equity (ME) which is computed by multiplying the share price and the number of shares outstanding. The third risk factor, HML (high minus low) implies the difference in returns on a portfolio of high book-to-market value (BE/ME) stocks and that of low BE/ME stocks. Risk factors, SMB and HML are similar to those in the Fama and French (1996) portfolio formation procedure. From 2010 through to 2014, 30 stocks are allocated to three groups which are small, medium or big ( $\mathrm{S}, \mathrm{M}$ or $\mathrm{B}$ ), based on whether their market equity (ME) is below or above the median ME for CSE stocks. CSE stocks are placed in an independent sort to three book-to-market equity (BE/ME) groups (low, medium or high; L, M, or H) based on the breakpoints for the bottom one-third, middle one-third and top one-third of the values of BE/ME for CSE stocks. The final nine portfolios are the intersection of the three $\mathrm{ME}$ and the three $\mathrm{BE} / \mathrm{ME}$ groups $(\mathrm{S} / \mathrm{L}, \mathrm{S} / \mathrm{M}, \mathrm{S} / \mathrm{H}, \mathrm{M} / \mathrm{L}, \mathrm{M} / \mathrm{M}, \mathrm{M} / \mathrm{H}, \mathrm{B} / \mathrm{L}$, $\mathrm{B} / \mathrm{M}$ and $\mathrm{B} / \mathrm{H})$. For example, the $\mathrm{S} / \mathrm{H}$ portfolio includes the stocks in the smallsize group that are also belonging to the high-BE/ME group. Excess returns on these portfolios are calculated by averaging the total excess returns of the indi- 
vidual stocks in these portfolios. Excess-return of an individual stock is the difference between total market return and the risk-free return.

Individual stock return in any month is calculated by CSE as:

$$
\mathrm{G}_{i}=\frac{F_{i} *(B D L+B D Z+1)-R * B D L+T-F_{i-1}}{F_{i-1}}
$$

where,

$G_{i}$ is the return of individual asset for month $i$,

$F_{i}$ is the closing price of the stock on the last trading day of month $i$,

$B D L$ : is the number of rights issues received during the month,

$B D Z$ : is the number of bonus issues received during the month,

$R$ : is the price for exercising rights (i.e. subscription price),

$T$ : is the amount of net dividends received during the month for a stock with a nominal value of TRY,

$F_{i-1}$ : is the closing price of a stock on the last trading day of the month $i-1$.

For each month SMB is the difference between the average of the returns on the three small-stock portfolios $(\mathrm{S} / \mathrm{L}, \mathrm{S} / \mathrm{M}$ and $\mathrm{S} / \mathrm{H})$ and the average of the returns on the three big stock portfolios $(\mathrm{B} / \mathrm{L}, \mathrm{B} / \mathrm{M}$ and $\mathrm{B} / \mathrm{H})$.

$$
\mathrm{SMB}=[(\mathrm{S} / \mathrm{L}+\mathrm{S} / \mathrm{M}+\mathrm{S} / \mathrm{H})-(\mathrm{B} / \mathrm{L}+\mathrm{B} / \mathrm{M}+\mathrm{B} / \mathrm{H})] / 3
$$

HML is the difference between the average of the returns on the three high$\mathrm{BE} / \mathrm{ME}$ portfolios $(\mathrm{S} / \mathrm{H}, \mathrm{M} / \mathrm{H}$ and $\mathrm{B} / \mathrm{H})$ and the average of the returns on the three low-BE/ME portfolios (S/L, M/L and $B / L)$.

$$
\mathrm{HML}=[(\mathrm{S} / \mathrm{H}+\mathrm{M} / \mathrm{H}+\mathrm{B} / \mathrm{H})-(\mathrm{S} / \mathrm{L}+\mathrm{M} / \mathrm{L}+\mathrm{B} / \mathrm{L})] / 3
$$

After the construction of SMB and HML portfolios for the right-hand side of equation, nine portfolios are constructed with a similar procedure in order to calculate excess portfolio returns for each month. All 30 stocks used in the analysis are sorted by size and distributed into three groups (S, M, B) such that first one (S) contains 10 stocks, the second (M) contains 10 stocks and the last (B) contains 10 stocks. Moreover, stocks are independently allocated to another three groups $(\mathrm{L}, \mathrm{M}, \mathrm{H})$ based on the book-to-market equity (BE/ME) such that first one (L) contains 10 stocks, the second $(\mathrm{M})$ contains 10 stocks and the last $(\mathrm{H})$ contains 10 stocks. Nine portfolios (S/L, S/M, S/H, M/L, M/M, M/H, B/L, $\mathrm{B} / \mathrm{M}, \mathrm{B} / \mathrm{H})$ are constructed as the intersection of the three size groups and three $\mathrm{BE} / \mathrm{ME}$ groups. For example, B/L portfolio is constructed by the stocks in the biggest third of firms and the lowest third of $\mathrm{BE} / \mathrm{ME}$ ratio.

\section{Empirical Findings}

According to the procedure described in Table 1, nine portfolios have been constructed with the combination of different market size and BE/ME ratios.

Table 2 indicates both SMB and HML portfolios of small size and low BE/ME have higher return $(0.0079 ; 0.007)$, whereas big and mid-sized and high premium earning portfolios have the lowest return $(-0.051)$. Highly risky portfolios 
Table 1. Number of stocks in each portfolio.

\begin{tabular}{ccccc}
\hline & & \multicolumn{3}{c}{ BE/ME } \\
\cline { 3 - 5 } & & Low & Medium & High \\
\hline \multirow{2}{*}{ S } & Small & 4 & 2 & 4 \\
& Medium & 4 & 2 & 4 \\
& Big & 2 & 6 & 2 \\
\hline
\end{tabular}

Table 2. Summary statistics.

\begin{tabular}{ccccccccc}
\hline Portfolio & Mean & SD & Portfolio & Mean & SD & Portfolio & Mean & SD \\
\hline S/LRP & -0.051 & 0.10633 & M/LRP & -0.048 & 0.10542 & B/LRP & -0.001 & 0.23217 \\
S/LSMB & 0.0079 & 0.38956 & M/LSMB & -0.009 & 0.41046 & B/LSMB & 0.0057 & 0.46384 \\
S/LHML & 0.007 & 0.12209 & M/LHML & -0.009 & 0.40977 & B/LHML & -0.006 & 0.46384 \\
S/MRP & -0.050 & 0.03954 & M/MRP & -0.051 & 0.03664 & B/MRP & -0.047 & 0.15311 \\
S/MSMB & 0.0005 & 0.05858 & M/MSMB & 0.0005 & 0.05674 & B/MSMB & -0.001 & 0.04188 \\
S/MHML & 0.0005 & 0.05858 & M/MHML & -0.001 & 0.05674 & B/MHML & 0.0003 & 0.06249 \\
S/HRP & -0.046 & 0.23712 & M/HRP & -0.051 & 0.02831 & B/HRP & -0.051 & 0.05864 \\
S/HSMB & 0.0011 & 0.09009 & M/HSMB & 0.0001 & 0.0669 & B/HSMB & -0.003 & 0.09937 \\
S/HHML & -0.029 & 0.93247 & M/HHML & 0.0020 & 0.05139 & B/HHML & 0.0027 & 0.09937 \\
\hline
\end{tabular}

Table 3. Mean and standard deviation.

\begin{tabular}{ccc}
\hline Factor & Mean & SD \\
\hline Rm-Rf & -0.0438 & 0.06003 \\
SMB (Size) & 0.0003 & 0.08454 \\
HML (Value) & -0.0035 & 0.11764 \\
\hline
\end{tabular}

(0.93247) earn negative return $(-0.029)$ which is unusual whereas average risky portfolios earn average return.

In Table 3, out of the three risk factors, HML is very risky $(\sigma-0.12)$ comparing to other two factors $(\sigma-0.06 ; 0.08)$. Both excess return and SMB are near to each other as far as risk is concern. But if we look at the mean (return) data, we see mean return of SMB is higher than HML whereas low risky portfolios have either low return or negative average. Fama and French (1995) also found that higher book to market ratio yields poor earnings.

Table 4 shows positive correlation between the factors. Although the relation between size and market cap is satisfactory, the relation of size and market cap with excess return is not satisfactory.

It is evident from Table 5 that portfolios are the blending of both positive and negative excess returns. Big sized portfolios $(\mathrm{B} / \mathrm{L}, \mathrm{B} / \mathrm{M}, \mathrm{B} / \mathrm{H})$ outperform small sized portfolios (S/L, S/M, S/H). Whereas low BE/ME portfolios (S/L, M/L, B/L) outperform high portfolios $(\mathrm{S} / \mathrm{H}, \mathrm{M} / \mathrm{H}, \mathrm{B} / \mathrm{H})$. Mid-size portfolios are outperformed by both small and big sized portfolios. Therefore, it can be concluded 
Table 4. Correlations.

\begin{tabular}{cccc}
\hline & SMB & HML & Excess Return \\
\hline SMB & 1 & $0.748^{* *}$ & $0.437^{* *}$ \\
HML & $0.748^{* *}$ & 1 & $0.374^{* *}$ \\
Excess Return & $0.437^{* *}$ & $0.374^{* *}$ & 1 \\
\hline
\end{tabular}

Note: ${ }^{* *}: 0.1 \%$ significance, ${ }^{* *}: 1 \%$ Significance, ${ }^{*}: 5 \%$ significance.

Table 5. Average rate of excess returns for portfolios and the standard deviation for dependent variables.

\begin{tabular}{|c|c|c|c|c|c|c|c|}
\hline & & \multicolumn{6}{|c|}{ Book to Market Equity (BE/ME) } \\
\hline & & \multicolumn{3}{|c|}{ Mean Excess Return } & \multicolumn{3}{|c|}{ Standard Deviation } \\
\hline & & Low (L) & Medium (M) & $\operatorname{High}(\mathrm{H})$ & Low & Medium & High \\
\hline \multirow{3}{*}{ 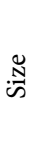 } & Small (S) & -0.0009 & 0.0006 & 0.0044 & 0.10654 & 0.03963 & 0.23705 \\
\hline & Medium (M) & 0.0022 & -0.0014 & -0.0010 & 0.10542 & 0.03664 & 0.02831 \\
\hline & Big (B) & 0.0043 & 0.0027 & -0.0002 & 0.23217 & 0.15311 & 0.05864 \\
\hline
\end{tabular}

that there is a rational size effect on the return in CSE and at the same time a weak effect of value (market cap) is also observed.

For the intercept, the null hypothesis is taken as zero and if the intercept term is significantly close to zero, it can be concluded that the model is correct. In the Table 6(a) it is observed that intercept values are significantly small and very close to zero. Fama and French (1993) also expressed that if the excess portfolio return is different from zero, it should be compensated for risk. Since, the three-factor model of French and Fama is based on risk premium, SMB and HML, the intercept values are supposed to be zero. Table 6(a) values (intercept) show that for the significance level of $0.1 \%, 1 \%$ and $5 \%$, all the values are close to zero which proves the French and Fama model performs well in terms of explaining excess portfolio returns

Fama and French also showed the effect of SMB and HML in their model. According to them, market return is 1 and any figures above 1 indicate additional risk and any figure below 1 indicates stock/portfolio risk is less than that of market. Table 6 (b) of slope coefficient of risk premium shows that all the coefficients are less than 1 which indicates that portfolios are not exposed to market risk and the return is not also satisfactory. In this circumstance, assumption of additional risk can increase the return to a greater extent as the portfolio risks are far away from the market risk.

Table 6(c) slope of co-efficient of SMB shows the big sized portfolios (B/L) contribute significant return (0.712) for assuming additional risks, but the scenario is just opposite in case of high BE/ME powered portfolios (H/S, H/B) and mid-size portfolios (M/L). Although rests are falling in between, it is seen a consistent relationship between size and the risk-return.

Table 6(d) shows negative slopes for all the portfolios. This indicates that 
Table 6. Regression returns of Fama and French three-factor model Intercept of excess portfolio return. (a) Slope co-efficient of Risk premium; (b) Slope co-efficient of Risk premium; (c) Slope co-efficient of SMB; (d) Slope co-efficient of HML.

(a)

\begin{tabular}{cccccccc}
\hline & \multicolumn{5}{c}{ Book to Market Equity (BE/ME) } \\
\cline { 3 - 7 } & & \multicolumn{5}{c}{ Intercept } \\
\cline { 2 - 7 } & Low & Medium & High & Low & Medium & High \\
\hline & Small (S) & $0.133^{* * *}$ & $0.068^{* * *}$ & $0.134^{* * *}$ & 0.000 & 0.000 & 0.000 \\
क & Medium (M) & $0.133^{* * *}$ & $0.067^{* * *}$ & $0.132^{* * *}$ & 0.000 & 0.000 & 0.000 \\
& Big (B) & $0.067^{* * *}$ & $0.200^{* * *}$ & $0.064^{* * *}$ & 0.000 & 0.000 & 0.000 \\
\hline
\end{tabular}

Note: ${ }^{* *}: 0.1 \%$ significance, ${ }^{* *}: 1 \%$ Significance, ${ }^{*}: 5 \%$ significance

(b)

\begin{tabular}{cccccccc}
\hline & \multicolumn{5}{c}{ Book to Market Equity (BE/ME) } \\
\cline { 3 - 7 } & & \multicolumn{5}{c}{ Slope (RP) } \\
\cline { 2 - 7 } & Low & Medium & High & Low & Medium & High \\
\hline \multirow{2}{*}{ * } & Small (S) & $0.218^{* * *}$ & $0.042^{* * *}$ & $0.489^{* * *}$ & 0.000 & 0.000 & 0.000 \\
& Medium (M) & $0.216^{* *}$ & $0.038^{* * *}$ & 0.058 & 0.000 & 0.000 & 0.000 \\
& Big (B) & 0.239 & 0.471 & 0.057 & 0.000 & 0.000 & 0.000 \\
\hline
\end{tabular}

Note: ${ }^{* *}: 0.1 \%$ significance, ${ }^{* *}: 1 \%$ Significance, ${ }^{*}: 5 \%$ significance

(c)

\begin{tabular}{cccccccc}
\hline & \multicolumn{5}{c}{ Book to Market Equity (BE/ME) } \\
\cline { 3 - 7 } & & \multicolumn{5}{c}{ Slope (SMB) } & \multicolumn{4}{c}{$p$-value } \\
\cline { 2 - 7 } & Low & Medium & High & Low & Medium & High \\
\hline \multirow{2}{*}{ क } & Small (S) & $0.256^{*}$ & 0.031 & $-0.033^{* * *}$ & 0.000 & 0.026 & 0.017 \\
& Medium (M) & -0.210 & 0.068 & $0.007^{* * *}$ & 0.000 & 0.000 & 0.087 \\
& Big (B) & 0.712 & 0.012 & $-0.449^{* * *}$ & 0.000 & 0.024 & 0.000 \\
\hline
\end{tabular}

Note: ${ }^{* * *}: 0.1 \%$ significance, ${ }^{* *}: 1 \%$ Significance, ${ }^{*}: 5 \%$ significance

(d)

\begin{tabular}{|c|c|c|c|c|c|c|c|}
\hline & & \multicolumn{6}{|c|}{ Book to Market Equity (BE/ME) } \\
\hline & & \multicolumn{3}{|c|}{ Slope (HML) } & \multicolumn{3}{|c|}{$p$-value } \\
\hline & & Low & Medium & High & Low & Medium & High \\
\hline \multirow{3}{*}{$\stackrel{\tilde{N}}{\pi}$} & Small (S) & -0.018 & -0.030 & -0.641 & 0.122 & 0.008 & 0.000 \\
\hline & Medium (M) & -0.218 & -0.040 & -0.082 & 0.000 & 0.001 & 0.000 \\
\hline & Big (B) & -0.718 & -0.019 & -0.131 & 0.000 & 0.110 & 0.000 \\
\hline
\end{tabular}

Note: ${ }^{* * *}: 0.1 \%$ significance, ${ }^{* *}: 1 \%$ Significance, ${ }^{*}: 5 \%$ significance

positive exposure to risk reduces the average return of portfolio while negative exposure increases the return. That means comparatively medium and low portfolios $(\mathrm{M} / \mathrm{L}, \mathrm{M} / \mathrm{M}, \mathrm{M} / \mathrm{B}, \mathrm{S} / \mathrm{L}, \mathrm{M} / \mathrm{H})$ can ensure better return than high 
$\mathrm{BE} / \mathrm{ME}$ portfolios $(\mathrm{B} / \mathrm{L}, \mathrm{S} / \mathrm{H})$. So, the size factor plays a vital role in explaining portfolio returns for medium and small size portfolios but it has no effect on large-scale portfolio returns.

Since, the significance value ( $p$ value) is zero it can be concluded that the null hypothesis is rejected that means the functioning of Fama-French three factor model in CSE is unaffected.

\section{Conclusion}

The objective of this research was to analyze the excess portfolio return variations by Fama and French three factor model. To attain this objective, market risk factor (RP), size risk factor (SMB), and book to market risk factor (HML) have been used. The model is found to be functionable at Chittagong Stock Exchange. This empirical study is based on the daily excess return of each stock from the year 2010 to December 2014. Nine portfolios were constructed in order to test the model. Statistical results show that big and medium size portfolios earn higher excess return than small size portfolios. On the other hand, BE/ME with high value earns higher return than that of low value. Intercept with zero values confirm the significant impact of other two factors on the excess portfolio return along with market risk factor. SMB can control the return of mid and small size portfolios but not big size portfolios. HML has effective influence on high BE/ME portfolios but the effect is ambiguous. This study finds less powerful results by applying the model. It may give irrational indications to the investors as Chittagong stock market is not efficient. Behavioral factors such as influence of syndicates, rumors, illiteracy of shareholders, absence of corporate governance, corruptions, bureaucratic harassment, political instability, irregular information flow etc. are responsible for this situation. Despite all these issues, it is observed that the result which has been obtained by applying this model is similar to other studies undertaken in different stock markets in the world.

\section{References}

Banz, R. W. (1981). The Relationship between Return and Market Value of Common Stocks. Journal of Financial Economics, 9, 3-18. https://doi.org/10.1016/0304-405X(81)90018-0

Basu, S. (1977). Investment Performance of Common Stocks in Relation to Their PriceEarnings Ratios: A Test of the Efficient Market Hypothesis. The Journal of Finance, 32, 663-682. https://doi.org/10.1111/j.1540-6261.1977.tb01979.x

Basu, S. (1983). The Relationship between Earnings Yield, Market Value, and Return for NYSE Common Stocks: Further Evidence. Journal of Financial Economics, 12, 129-156. https://doi.org/10.1016/0304-405X(83)90031-4

Black, F. (1972). Capital Market Equilibrium with Restricted Borrowing. The Journal of Business, 45, 444-455. https://doi.org/10.1086/295472

Black, F., Jensen, M. C., \& Scholes, M. (1972). The Capital Asset Pricing Model: Some Empirical Tests. In M. C. Jensen (Ed.), Studies in the Theory of Capital Markets (pp. 79-121). New York: Praeger.

Brav, A., Geczy, C., \& Gompers, P. A. (2000). Is the Abnormal Return Following Equity 
issuance Anomalous? Journal of Financial Economics, 56, 209-249.

https://doi.org/10.1016/S0304-405X(00)00040-4

Breeden, D. T. (1979). An Intertemporal Asset Pricing Model with Stochastic Consumption and Investment Opportunities. Journal of Financial Economics, 7, 265-296. https://doi.org/10.1016/0304-405X(79)90016-3

Carhart, M. M. (1997). On Persistence in Mutual Fund Performance. The Journal of Finance, 52, 57-82. https://doi.org/10.1111/j.1540-6261.1997.tb03808.x

Chan, K. C., Hamao, Y., \& Lakonishok, J. (1991). Fundamentals and Stock Returns in Japan. J Finance, 46, 1739-1789. https://doi.org/10.1111/j.1540-6261.1991.tb04642.x

Chan, K., Hameed, A., \& Tong, W. (2000). Profitability of Momentum Strategies in the International equity Markets. The Journal of Financial and Quantitative Analysis, 35, 153-172. https://doi.org/10.2307/2676188

Chui, A. C. W., \& Wei, K. C. (2000). John and Titman, Sheridan, Momentum, Legal Systems and Ownership Structure: An Analysis of Asian Stock Markets. https://ssrn.com/abstract $=265848$

Chui, A., \& Wei, K. C. (1998). Book-to-Market, Firm Size and the Turn-of-the-Year Effect: Evidence from Pacific-Basin Emerging Markets. Pacific-Basin Finance Journal, 6, 275-293. https://doi.org/10.1016/S0927-538X(98)00013-4

Daniel, K., Grinblatt, M., Titman, S., \& Wermers, R. (1997). Measuring Mutual Fund Performance with Characteristics-Based Benchmarks. The Journal of Finance, 52, 1035-1058. https://doi.org/10.1111/j.1540-6261.1997.tb02724.x

Drew, M. E., \& Veeraraghavan, M. (2003). Beta, Firm Size, Book-to-Market Equity and Stock Returns: Further Evidence from Emerging Markets. Journal of the Asia Pacific Economy, 8, 354-479.

Fama, E. F., \& French, K. R. (1992). The Cross-Section of Expected Stock Returns. The Journal of Finance, 47, 427-465. https://doi.org/10.1111/j.1540-6261.1992.tb04398.x

Fama, E. F., \& French, K. R. (1993). Common Risk Factors in the Returns on Stocks and Bonds. Journal of Financial Economics, 33, 3-56. https://doi.org/10.1016/0304-405X(93)90023-5

Fama, E. F., \& French, K. R. (1995). Size and Book-to-Market Factors in Earnings and Returns. The Journal of Finance, 50, 131-155. https://doi.org/10.1111/j.1540-6261.1995.tb05169.x

Fama, E. F., \& French, K. R. (1996). Multifactor Explanations of Asset Pricing Anomalies. The Journal of Finance, 51, 55-84. https://doi.org/10.1111/j.1540-6261.1996.tb05202.x

Fama, E. F., \& French, K. R. (2004). The Capital Asset Pricing Model: Theory and Evidence. The Journal of Economic Perspectives, 18, 25-46. https://doi.org/10.1257/0895330042162430

Fama, E. F., \& MacBeth, J. (1973). Risk, Return, and Equilibrium: Empirical Tests. Journal of Political Economy, 81, 607-636. https://doi.org/10.1086/260061

Fong, W. M., Wong, W. K., \& Lean, H. H. (2005). International Momentum Strategies: A Stochastic Dominance Approach. The Journal of Finance, 8, 89-109. https://doi.org/10.1016/j.finmar.2004.08.001

Gaunt, C. (2004). Size and Book to Market Effects and the Fama French Three Factor Asset Pricing Model: Evidence from the Australian Stockmarket. Accounting \& Finance, 44, 27-44. https://doi.org/10.1111/j.1467-629x.2004.00100.x

Grundy, B. D., \& Martin, J. S. (2001). Understanding the Nature of the Risks and the Sources of the Rewards to Momentum Investing. The Review of Financial Studies, 14, 29-78. https://doi.org/10.1093/rfs/14.1.29

Herrera, M. J., \& Lockwood, L. J. (1994). The Size Effect in the Mexican Stock Market. 
Journal of Banking \& Finance, 18, 621-632.

https://doi.org/10.1016/0378-4266(93)00010-M

Ho, Y. W., Strange, R., \& Piesse, J. (2000). CAPM Anomalies and the Pricing of Equity: Evidence from the Hong Kong Market. Journal of Applied Economics, 32, 1629-1636. https://doi.org/10.1080/000368400419014

Jaffe, J., Keim, D. B., \& Westerfied, R. (1989). Earnings Yields, Market Values, and Stock Returns. The Journal of Finance, 44, 135-34. https://doi.org/10.1111/j.1540-6261.1989.tb02408.x

Jegadeesh, N., \& Titman, S. (1993). Returns to Buying Winners and Selling Losers: Implications for Stock Market Efficiency. The Journal of Finance, 48, 65-91. https://doi.org/10.1111/j.1540-6261.1993.tb04702.x

Kim, D., \& Kim, M. (2003). A Multifactor Explanation of Post-Earnings Announcement Drift. The Journal of Finance, 38, 383-398. https://doi.org/10.2307/4126756

L'Her, J., Masmoudi, T., \& Suret, J. (2004). Evidence to Support the Four-Factor Pricing Model from the Canadian Stock Market. Journal of International Financial Markets, Institutions \& Money, 14, 313-328. https://doi.org/10.1016/j.intfin.2003.09.001

Lam, S. K. (2002). The Relationship between Size, Book-to-Market Equity Ratio, Earnings-Price Ratio, and Return for the Hong Kong Stock Market. Global Finance Journal, 13, 163-179. https://doi.org/10.1016/S1044-0283(02)00049-2

Lau, S. T., Lee, C. T., \& McInish, T. H. (2002). Stock Returns and Beta, Firm Size, E/P, $\mathrm{CF} / \mathrm{P}$, Book-to-Market, and Sales Growth: Evidence from Singapore and Malaysia. Journal of Multinational Financial Management, 12, 207-222. https://doi.org/10.1016/S1042-444X(01)00051-2

Liew, J., \& Vassalou, M. (2000). Can Book-to-Market, Size and Momentum Be Risk Factors That Predict Economic Growth? The Journal of Finance, 57, 221-245. https://doi.org/10.1016/S0304-405X(00)00056-8

Lintner, J. (1965). Security Prices, Risk and Maximal Gains from Diversification. The Journal of Finance, 20, 587-615.

Mukherji, S., Dhatt, M. S., \& Kim, Y. H. (1997). A Fundamental Analysis of Korean Stock Returns. Journal of Financial and Quantitative Analysis, 53, 75-80. https://doi.org/10.2469/faj.v53.n3.2086

Reinganum, M. R. (1981). Misspecification of Capital Asset Pricing: Empirical Anomalies Based on Earnings' Yields and Market Values. The Journal of Finance, 1, 19-46. https://doi.org/10.1016/0304-405X(81)90019-2

Rosenberg, B., Reid, K., \& Lanstein, R. (1985). Persuasive Evidence of Market Inefficiency. The Journal of Portfolio Management, 11, 9-16. https://doi.org/10.3905/jpm.1985.409007

Sharpe, W. F. (1964). Capital Asset Prices: A Theory of Market Equilibrium under Conditions of Risk. The Journal of Finance, 19, 425-445.

Shum, W. C., \& Tang, Y. N. (2005). Common Risk Factors in Returns in Asian Emerging Stock Markets. International Business Review, 14, 695-715. https://doi.org/10.1016/j.ibusrev.2005.09.001

Wermers, R. (1997). Momentum Investment Strategies of Mutual Funds, Performance Persistence, and Survivorship Bias. Unpublished Working Paper, University of Colorado. http://bus.colorado.edu/faculty/wermers/

Wong, K. A., \& Lye, M. S. (1990). Market Values, Earnings' Yields and Stock Returns: Evidence from Singapore. Journal of Banking \& Finance, 14, 311-321.

https://doi.org/10.1016/0378-4266(90)90052-4 